\title{
Lessons Learned from Developing a Learning-Focused Classroom Observation Form
}

Steven K. Jones, Kenneth S. Sagendorf, D. Brent Morris, David Stockburger, Evelyn T. Patterson United States Air Force Academy

We thank Bob Noyd for sharing his insights on an early version of the observation form, as well the Academy's Biology, Chemistry, and Physics Departments for assistance and feedback in our initial pilot testing.

At the United States Air Force Academy, we are attempting to go through a cultural transformation, making an overt shift toward a more learningfocused paradigm. In this chapter, we describe the nature of this transformation, as well as why we have chosen to move in this direction. We also describe one specific initiative we have undertaken: the development of a new learning-focused classroom observation form. We conclude by sharing a baker's dozen lessons we have learned about classroom observation, effective teaching, and faculty development in general as a result of having developed this form.

At the United States Air Force Academy (USAFA), we are attempting to go through a cultural transformation, making an 
overt shift from an instruction-centered paradigm toward a more learning-focused paradigm (Barr \& Tagg, 1995; Huba \& Freed, 2000; Tagg, 2003). As part of that transformation, we have taken on the ambitious task of operationally defining the learning focus within a classroom observation form. In this chapter, we describe our learning-focused transformation, explain why we have chosen to make it, and introduce readers to our observation form. We conclude with a baker's dozen lessons we've learned about classroom observation, teaching, and faculty development in general by engaging in this effort.

\section{About the Air Force Academy}

The mission of USAFA is to "educate, train, and inspire men and women to become officers of character, motivated to lead the United States Air Force in service to our nation." Located in Colorado Springs, Colorado, USAFA is a four-year, undergraduate institution, with an enrollment of approximately 4,400 students. These students (whom we call cadets) participate in a rigorous program consisting of academic courses (both within an academic major and within 102 semester hours of core classes required of all cadets), military training, mandatory athletic participation, and character-development programs. Upon graduation, cadets receive a Bachelor of Science degree and a commission as a Second Lieutenant in the United States Air Force.

One of the unique characteristics of USAFA is the high level of turnover we experience on our faculty. By design, the Academy tries to expose cadets to many different role models from the active duty Air Force. As a result, approximately 75 percent of our faculty members are military officers, almost all of whom have recently served in the operational Air Force. Furthermore, most of the military officers on the faculty are assigned to teach at USAFA for three to four years, after which time they will return to operational duty. The result is a military faculty that turns over very rapidly; we typically welcome approximately 125 new faculty members each year.

This rapid turnover poses a significant faculty development challenge. For the most part, our military faculty are not career educators, and many of them come to USAFA with little or no 
teaching experience. Furthermore, the short-term nature of their assignment is such that they must get up to speed with regard to their teaching duties very quickly. Obviously, having a robust faculty development program is an absolute must.

As an institution, we have responded to the faculty development challenge by creating a series of intentional learning experiences for faculty. Our Center for Educational Excellence provides an extensive faculty orientation program for new faculty members, as well as follow-on faculty development workshops throughout the academic year. We also use a "course director" system. Faculty members work under an experienced faculty member who is responsible for organizing and guiding a particular course. Therefore, new instructors typically step into existing courses with pre-written syllabi, course materials, and at least some assessment mechanisms. Within individual academic departments, this scaffolding is further supplemented by peer and supervisor mentoring, to include systematic classroom observation programs. Enhancing these classroom observation programs is the focus of this chapter.

\section{Our Move to a Learning-Focused Paradigm}

An intentional shift toward a learning focus is certainly not unique to the Air Force Academy. Indeed, nationwide, colleges and universities are engaging in conversations about what they want their students to learn, how they can best facilitate that learning, and how they can use assessment data to improve student learning in the future.

Several significant factors have led to the shift toward a learning focus. One has been an increasing call nationwide for accountability within colleges and universities. Several recent authors (for example, Bok, 2006; Hersh \& Merrow, 2005) have provided critical examinations of college practices and have questioned whether colleges are accomplishing everything that they can (or should) be accomplishing. The issue of increased accountability has also gained national political attention, particularly with the release of the Spellings Commission Report, "A Test of Leadership: Charting the Future of U.S. Higher Education" (U.S. 
Department of Education, 2006). It is clear that colleges and universities are being called upon as never before to demonstrate that they actually do promote meaningful learning in their students.

The increased emphasis on learning has also appeared in changing accreditation requirements. For example, the Higher Learning Commission of the North Central Association (which accredits USAFA) has recently adopted new accreditation criteria for all of its member schools. These criteria demand that we clearly articulate the learning goals we have for cadets, create systems that allow that learning to take place, and then assess the extent to which those learning goals are met (Higher Learning Commission, 2007).

The national call for accountability has coincided with heightened discussions of what types of learning should take place in college in the first place. In today's information age, the volume of readily available knowledge is growing exponentially. What is "known" today is likely to be very different from what will be "known" even a few years from now. Furthermore, modern technology (the Internet, PDAs, cell phones, and so on) is making the information that is known increasingly easy to access. Therefore, although a college education must still build students' foundational knowledge, it is clear that, by itself, knowledge acquisition is increasingly inadequate. In a national survey commissioned by the Association of American Colleges and Universities (2007), 63 percent of employers reported that recent college graduates lacked the intellectual and practical skills (teamwork, critical thinking skills, and so on) required in our increasingly global economy. Fifty-six percent of the employers also indicated that colleges and universities should do more to promote a sense of integrity and ethics. Clearly, organizing our college classes around acquisition of disciplinary knowledge is not enough. Other types of learning are needed as well.

At the Air Force Academy, we have spent substantial time over the last two years rethinking the desired outcomes of an Academy education. This included considerable consultation with AAC\&U, whose recent (2007) publication "College Learning for the New Global Century" spells out the "essential learning outcomes" for students in the twenty-first century. Another major influence on outcomes development has been the United States Air Force, which 
has released similar guidance about the competencies required of new Air Force officers. The result of this work was the publication of new USAFA outcomes, shown in Table 11.1. These outcomes have been endorsed at all levels of the institution and now provide a target for all faculty, staff, and cadets.

The final factor contributing to the increased emphasis on learning is the burgeoning body of research about the factors that promote learning in college students. For example, educational research is very clear that students are not just passive vessels to be filled with content. Instead, they are active constructors, discoverers, and transformers of knowledge (see Campbell \& Smith, 1997; Hake, 1998; for a more comprehensive discussion, see National Research Council, 2000). Therefore, if we at the Air Force

\section{Table 11.1. USAFA Outcomes}

Commission leaders of character who embody the Air Force core values are...

... committed to Societal, Professional, and Individual Responsibilities

Ethical Reasoning and Action

Respect for Human Dignity

Service to the Nation

Lifelong Development and Contributions

Intercultural Competence and Involvement

.. empowered by integrated Intellectual and Warrior Skills

Quantitative and Information Literacy

Oral and Written Communication

Critical Thinking

Decision Making

Stamina

Courage

Discipline

Teamwork

.. grounded in essential Knowledge of the Profession of Arms and the Human and Physical Worlds

Heritage and Application of Air, Space, and Cyberspace Power

National Security and Full Spectrum of Joint and Coalition Warfare

Civic, Cultural, and International Environments 
Academy have any hope of achieving our lofty institutional outcomes, it is clear that our pedagogy must be one that is intentionally focused on cadet learning. As Biggs (1999, p. 63) points out, we can no longer say, "I taught them, but they didn't learn."

\section{How Our Learning-Focused Paradigm Works}

Saying that one is intentionally focused on cadet learning is one thing; actually doing it may be something else. As a result, we have found it necessary to discuss with our faculty what a learning focus really means. The basis of many of our conversations has been what course designers (for example, Fink, 2003; Wiggins, 1998) call "backwards design." That is, when considering a lesson, a course, or even the curriculum as a whole, the faculty member needs to ask, "What is it that I hope a cadet will get from this experience (lesson, course, four-year education) when it is over?" In short, our lessons, courses, and curricula need to be designed with the desired end-point in mind. We then need to use best pedagogical practices to develop learning experiences (in and out of the classroom) that are aligned with those desired learning goals, as well as build in timely, aligned assessment mechanisms to ensure that the desired learning actually took place. The results of those assessments are then fed back to both cadets and faculty to improve learning in the future. Our depiction of this learning-focused cycle is shown in Figure 11.1.

Figure 11.1. USAFA's Learning-Focused Cycle

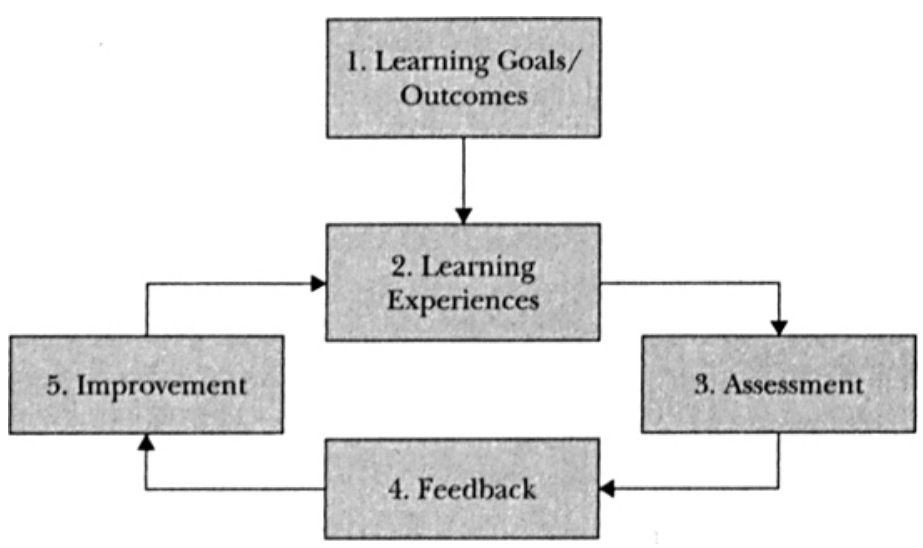


As we have worked with this model, we have discovered the critical importance of alignment between the learning goals, learning experiences, assessments, and feedback. Each component of the cycle must reflect and support the others in order to optimize student learning. Unfortunately, we have discovered that perfect alignment does not always happen. For example, consider a class that is designed to help cadets develop more sophisticated critical thinking skills. To be "in alignment," the learning experiences cadets have in that class should be designed to give them practice honing these skills, not just learning about the content of the discipline. The cadets should be assessed on how well they can think critically, not just on how they answer multiple-choice questions about course readings. The feedback the cadets receive should be aimed toward helping them think more critically, not just aimed at sorting them into piles, based on their grades in the course. And when cadets in the class try to improve, they should focus on improving specific thinking skills for which they are weak, not just focus on "working harder" in the class. Alignment means that everything in the class should be in line with the desired learning outcomes for the class.

\section{Development of a Classroom Observation Form}

We have spent many hours discussing the learning-focused cycle with faculty members at our institution, and it has been introduced in faculty convocations, regular campuswide e-mails and departmental immersions by our dean, and our internal campus publications. However, our faculty colleagues have said that they want more details. What would it look like to teach in a learningfocused way? How might teaching in this way affect faculty on a day-to-day basis? And what is the research evidence that would suggest that these changes are a good idea anyway? We have also faced tough questions from USAFA leadership, such as How are things going with the learning focus? and Is this having an impact on how faculty are teaching? In order to address each of these challenging questions, we designed a rubric so that our faculty had an instrument to measure the extent to which their teaching was, indeed, learning-focused. The current version of our rubric is included in Appendix A. 
This rubric has gone through many, many revisions. When using previous versions, we frequently found ourselves using the rubric in a class, only to discover something we had not previously thought of. Or we had the realization that the rubric did not allow us to provide the best feedback to individual instructors. We even realized that we (members of the Academy's administrative staff) may not even be the best people to use the rubric in classroom observations in the first place. In short, we have learned a great deal. Table 11.2 summarizes the baker's dozen most important lessons we have learned as our rubric has evolved. Each of those lessons is described in more detail later in the chapter.

\section{Table 11.2. Lessons Learned from Developing Our Classroom Observation Form}

Our Baker's Dozen

What We Have Learned About Creating an Observation Form

1. Stay true to your educational philosophy.

2. Ensure that the form is grounded in the literature.

3. Highlight those things that are most important.

4. Make the form general enough that it can be used in multiple disciplines.

5. Observe courses multiple times.

6. Focus on the course (rather than the faculty member) as the level of analysis.

\section{What We Have Learned About Effective Teaching}

7. Teaching cannot be boiled down to a recipe.

8. Effective course design is critical.

What We Have Learned About the Process of Faculty Development

9. Know (and take advantage of) the institutional context.

10. Be sure to practice what you espouse.

11. Get faculty involved in the process.

12. Seek outside assistance.

13. Be flexible and willing to learn. 


\section{What We Have Learned About Creating an Observation Form}

1. Stay true to your educational philosophy. We intentionally designed our observation form to be an operationalization of the learningfocus cycle, which our institution has endorsed. Therefore, we found it very important that the structure of the form correspond with the steps of the cycle. This is why, in the current form, we created distinct sections for 1) learning goals, 2) learning experiences, 3) assessment, and 4) feedback.

2. Ensure that the form is grounded in the literature. Faculty are understandably skeptical about new things, especially when those new things appear to make demands on their time or steer them in directions they are not accustomed to going. As a result, many of our faculty asked us to provide them with the relevant literature dealing with learning goals, learning experiences, assessment, and feedback. We quickly annotated every component of our observation rubric with the most salient research, and these annotations are reflected in our current form.

3. Highlight those things that are most important. In earlier versions of our form, we attempted to be as comprehensive as possible. So, in the "learning experiences" section, we tried to identify all of the possible factors that would distinguish effective from ineffective pedagogy. As we pilot tested those early versions, however, we found it very difficult to focus on all dimensions of the form while observing a class. Furthermore, some dimensions defied reliable quantification. We realized that we needed to make the form easier for observers to use.

To do this, we identified two "top-tier" questions for each section of the observation rubric. These top-tier questions, shown at the top of each section of the existing form, reflected those items that our pilot testing suggested were the most important things to look for. We also simplified the structure of the top-tier questions (making them simple YES-NO distinctions) so that we could answer them more reliably. These changes have simplified the task of observing classes tremendously. And although we can still provide informal feedback to instructors on other areas of the form (that is, in those items at the bottom of each section), we have found that the top-tier questions help us home in on our highest-priority area. 
4. Make the form general enough that it can be used in multiple disciplines. Different disciplines require different ways of thinking (Arons, 1979, 1997; Donald, 2002; Durisen \& Pilachowski, 2004), so a teaching technique that is effective in a chemistry course may not necessarily be effective in a history course. Therefore, we were careful to include general principles in our form, rather than more specific techniques. For example, the research (King, 1993; National Research Council, 2000) suggests that cadets will learn more if they do so within a conceptual framework, so we included an item reflecting this finding on our form. However, we did not try to prescribe what those conceptual frameworks should be, how those frameworks should be communicated to cadets, or how the frameworks should be invoked in class.

A significant benefit of having a general-purpose observation form is that instructors from within a particular discipline are able to observe classes in other disciplines. Our hope is that creating a general-purpose form will facilitate conversations about teaching and learning across departmental boundaries. The cross-disciplinary nature of this form is also consistent with other initiatives on our campus (for example, interdisciplinary "outcome teams" responsible for developing the USAFA outcomes across the entire curriculum) that aim to foster greater levels of integration across different functional units.

5. Observe courses multiple times. Our original observation form was written to allow a visitor to observe and comment on a single class. During our pilot testing, however, we realized that expecting faculty to be in the "facilitates learning best" category for every entry during every single class was unrealistic. (For example, we know that cadets benefit when they interact with one another in class, but it is probably unrealistic to expect that cadets will interact with one another during every single class session.) Therefore, we feared that our form could be perceived as either setting faculty up for failure or being so unattainable that faculty would simply write it off as unreasonable.

With this in mind, we made an important change. Rather than frame the form in terms of a single classroom observation, we framed it as a frequency measure, to be used over the course of an entire semester. So the data that we ultimately gather would not be whether cadets interacted with each other in a given class 
session; instead, it would be the percentage of class sessions that cadets interacted with one another. This reframing acknowledged that no instructor would meet all of the criteria for "facilitates learning best" in every class, but it would capture the prevalence of best practices across the semester. Obviously, informal feedback can still be provided to instructors on the basis of any single classroom observation.

6. Focus on the course (rather than the faculty member) as the level of analysis. In a similar vein, our original form was designed to focus attention on individual instructors ("Today, we're going to observe Dr. Smith."). However, after only a short time, it became apparent that our faculty were reluctant to endorse an observation form because the results might be used against them. Our original version was perceived as being too threatening.

We tried to make the observation process less threatening by focusing the form on the course ("Today, we're going to observe Physics 110.") rather than on an instructor. The Academy's course director system makes this quite easy to do. For instance, if we observe multiple sections of a core physics course, we could aggregate the data across the entire course before reporting the results to the course director.

\section{What We Have Learned About Effective Teaching}

1. Teaching cannot be boiled down to a recipe. Especially among our young, inexperienced faculty, it is not uncommon to hear questions about the "right" way to teach a course. However, there is no pedagogical silver bullet. The available research does have much to say about pedagogical best practices, but there is clearly no single best way for faculty members to do things. This truism has become even more apparent as we have observed a variety of courses, instructors, and teaching styles. Our general-purpose form does highlight some of the best practices (recognizing that doing so might encourage people to use them), but our goal is certainly not to prescribe any single teaching method.

2. Effective course design is critical. When we began pilot testing our observation rubric, we expected that we would spend most of our time talking about the pedagogies used by individual instructors. Although that has certainly happened to a degree, we have 
actually found ourselves talking even more about course design. If a course is not intentionally designed to promote deep learning of meaningful student-learning outcomes, it will not score well on the rubric, no matter how it is taught. Therefore, we are currently planning an extended retreat for the course directors of our core courses, with the goal of helping them design the very best courses possible across the entire institution (for example, by clearly articulating their course learning goals and aligning them with the USAFA outcomes).

\section{What We Have Learned About the Process of Faculty Development}

1. Know (and take advantage) of the institutional context. The Air Force Academy is a unique institution, and some aspects of what we're doing here might not work successfully at other institutions. However, the same could likely be said about most colleges and universities, as each one has its own unique culture and its own way of doing business. The key is to be aware of the unique aspects of the institutional culture and to take advantage of them.

For instance, consider the unique faculty development challenges that we face at the Air Force Academy. Because of these challenges, our Center for Educational Excellence (which consists of four of the five authors of this chapter) is called on to take a proactive role. Our administration empowers us to promote a culture of learning and development at our institution-a role that involves us in institutional discussions beyond faculty development to include institutional outcomes, curriculum development, and assessment. We recognize that our situation may not be shared by faculty developers at other institutions. However, it is that culture, in part, that has allowed us to make quick progress with our observation form.

Another unique characteristic of the Air Force Academy is that robust classroom observation programs are already in place in departments across our campus. As a result, the idea of faculty members observing one another's classes is not new here. Rather than starting a new observation program, then, we see our efforts as a supplement to the programs that already exist, providing 
another way to give open, constructive feedback to faculty members about what they are doing in the classroom.

2. Be sure to practice what you espouse. Our learning-focused cycle is based largely on the idea of backwards design (Fink, 2003; Wiggins, 1998). That is, we encourage our faculty members to clarify their goals and then act in ways that are well suited to accomplish those goals. As we have proceeded, we have found it valuable to apply the same guidance to ourselves- to clarify the goals for our observation rubric and then behave in ways that are intentionally designed to accomplish them. In our case, we had three goals for our form: 1) to operationalize the learning focus for our faculty, 2) to encourage the use of best educational practices on our campus, and 3) to collect data to measure our improvement. We created our form to accomplish these three goals, and we have assessed, honed, and reassessed it many times to accomplish those goals more effectively. We will continue to do so.

3. Get faculty involved in the process. We are all too familiar with the struggle to bridge the gap that can sometimes exist between faculty and administration. Certainly, the faculty will not respond well if an observation form is perceived as something imposed on them from outsiders. Therefore, we have found it helpful to enlist the assistance of faculty members at every step of the way. Our goal is to have faculty take ownership of the learning focus (and consequently of the learning-focused observation rubric), so their engagement in the process, both in designing the form and in performing the observations, is absolutely necessary.

4. Seek outside assistance. At AAC\&U's 2007 Greater Expectations Institute in Burlington, Vermont, we had the opportunity to share an earlier version of our form with Dee Fink. His 2003 book, Creating Significant Learning Experiences, helped us shape our rubric and frame our thinking about what was needed to help our faculty rethink teaching as facilitating student learning. Dr. Fink provided us with encouraging words that assured us we were headed in the right direction. He also suggested some areas that needed to be strengthened and gave us ideas for possible improvements. That external assistance was invaluable.

5. Be flexible and willing to learn. In each of our classroom observations, between two and four observers have been in the 
classroom using the rubric. After each observation, we have met to gauge our agreement on each item of the form and to brainstorm what improvements to the form could be made. As a result, our form has gone through many modifications, and we have learned a great deal along the way. Despite the difficulties and strains on our patience, our work on the form has been very rewarding, and we are convinced that our persistent efforts have been worth it.

\section{Our Use of the Form Thus Far}

To date, we have piloted our form in the introductory classes of three departments: Biology, Chemistry, and Physics. In each department, we observed the instructors of a core course, required for all students on our campus.

One of the core courses we observed has recently gone through a significant redesign in an effort to make it well aligned with the learning focus. In that course, we consistently observed well-constructed learning goals and learning experiences. As a result, our primary contributions were in the areas of assessment and feedback. Following debriefs with faculty of that course, the course director has increased his focus on designing aligned assessment and feedback tools. The department is paying particular attention to course exams and other graded components of the class.

In the other two departments we observed, our experiences were somewhat different. We frequently observed faculty writing outlines on the board about what would be covered in a given class period. However, we rarely saw clearly articulated learning goals that were phrased in terms of what cadets would know or be able to do as a result of that coverage. The lack of clear learning goals made it challenging for us to make reliable judgments about the alignment of learning experiences, assessment, and feedback. For instance, it was difficult to judge whether the learning experiences in a class were well aligned with the learning goals when it was not immediately obvious what the underlying learning goals really were. We shared this dilemma with faculty teaching these courses, and, in one case, the discussion led to the creation of lesson-by-lesson learning goals. We are delighted that, even in its infancy, our use of the observation form has begun to 
drive instructor behavior toward strategies that improve student learning.

\section{Future Uses of the Form}

As we look ahead to the future, we see our observation form as being helpful at multiple levels of the Air Force Academy. At the level of the specific class session, this rubric provides us with a good catalyst for dialogue with individual instructors. By helping faculty become more aware of pedagogical best practices, the observation form can also provide faculty with a platform for their own self-evaluation, reflection, and self-improvement. Ultimately, it will also help faculty determine how well they are reaching and engaging their students.

At a course level, the observation form will enable our course directors to measure the degree to which their courses are learningfocused. This information will be especially helpful in improving courses over time and measuring the impact of specific course changes. For instance, what is the impact of changing (or even clarifying) the specific learning goals for particular lessons or sets of lessons in a course? How do such changes affect the overall "learning focus" of the course as a whole? Consistent use of this rubric would allow course directors to answer these questions.

At an institutional level, the observation form may furnish a different way of collecting and examining data on our educational practices. Although it does not measure student learning directly, the data it generates most likely correlate with direct measures of student learning. For instance, knowing the percentage of courses that have clearly articulated learning goals or offer assessments that are well aligned with those learning goals would probably help us predict, at least to some degree, the amount of meaningful learning that takes place in those courses. In this regard, the form could be used as a complement to the National Survey of Student Engagement (2005), which our cadets take every three years.

Although not our immediate intent, it is even conceivable that some version of this observation rubric could be used across multiple institutions. With the demand for accountability on campuses across the country, colleges and universities are struggling to find ways to measure the quality of their educational processes. Many 
have expressed concerns about ranking systems used in publicátions such as U.S. News $\mathcal{E}^{\circ}$ World Report, but a better solution to the quality controversy is not obvious. As one way to fill the void, perhaps colleges and universities could form consortia that volunteer to use this kind of classroom observation rubric on their campuses. Members of each consortium would share the resulting data and, ideally, their best practices as well.

Beyond classroom observation, our form could also provide the basis of a revised end-of-semester survey for cadets at the end of the semester. Similar to most institutions, our cadets complete surveys at the end of each semester about each of their courses. Currently, we are exploring the possibility of updating our survey so that it more closely reflects the steps of the learning-focused cycle. Our cadets are, arguably, the best observers of what goes on in their classes; aligning the survey with the classroom observation could give our faculty (as well as the institution as a whole) good feedback about the extent to which they are engaged in effective learning practices.

\section{Conclusion}

As with anything we work on in our positions, we know that the learning-focused classroom observation form is not a panacea. Fink (2003) describes six critical issues that need to be addressed to support faculty that seek to improve teaching and learning: 1) awareness, 2) encouragement, 3) time, 4) resources, 5) cooperative students, and 6) recognition and reward. Deciding to develop a classroom observation form addresses only a few of these issues. However, we have found doing so to be a valuable investment of our time and energy, and we look forward to implementing it more broadly in the months and years to come. It is our sincere hope that doing so will help move the Air Force Academy forward in its quest to be a truly learning-focused institution. 


\section{Appendix A}

\section{Learning-Focused Observation Form}

(Note: The superscripts that follow the heading "Learning Goals" identify the references used to develop that section of the form. Please see "Sources Used in the Development of the Form" at the end of this appendix.)

The following form is designed to provide feedback to instructors, course directors, and senior leadership about the extent to which learning-focused practices are being used in USAFA courses. Data gathered using this form will be summarized by course, rather than by individual instructor.

COURSE BEING OBSERVED:

DATE: Learning Goals ${ }^{(4,5,7,8,11,13)}$

1. Are there learning goals specific to today's class? YES NO

2. Have learning goals been clearly articulated in terms of what cadets will know or be able to do?

YES NO

If "YES," how did cadets receive feedback? 


\section{Follow-on feedback areas:}

\begin{tabular}{|c|c|c|}
\hline Criterion & $\begin{array}{l}\text { Facilitates } \\
\text { Learning Best }\end{array}$ & $\begin{array}{l}\text { In Contrast } \\
\text { to . . }\end{array}$ \\
\hline \multirow[t]{2}{*}{$\begin{array}{l}\text { Challenging, yet } \\
\text { achievable }\end{array}$} & $\begin{array}{l}\text { LGs are appro- } \\
\text { priate for cadets' } \\
\text { developmental } \\
\text { level (challeng- } \\
\text { ing, yet achiev- } \\
\text { able) }{ }^{(5,9,11,20)}\end{array}$ & $\begin{array}{l}\text { LGs too lofty or } \\
\text { too simplistic for } \\
\text { cadets' develop- } \\
\text { mental level }\end{array}$ \\
\hline & $\begin{array}{l}\text { LGs reflect } \\
\text { combination } \\
\text { of knowl- } \\
\text { edge, skills, \& } \\
\text { responsibili- } \\
\text { ties }(3,4,5,8,10 \text {, } \\
11,15,21)\end{array}$ & $\begin{array}{l}\text { LGs reflect } \\
\text { only knowl- } \\
\text { edge } \\
\text { acquisition }\end{array}$ \\
\hline
\end{tabular}

\section{Learning Experiences}

1. Are cadets engaged with course material, above and beyond merely being passive recipients of information? $(11,12,14,16,17)$

2. Are learning experiences well-aligned with learning goals? $(7,10)$ 


\section{Follow-on feedback areas:}

\begin{tabular}{|c|c|c|}
\hline Criterion & $\begin{array}{l}\text { Facilitates } \\
\text { Learning Best }\end{array}$ & $\begin{array}{l}\text { In Contrast } \\
\text { to . . }\end{array}$ \\
\hline $\begin{array}{l}\text { The role of the } \\
\text { instructor }\end{array}$ & $\begin{array}{l}\text { Facilitate cadet } \\
\text { learning / } \\
\text { accomplish- } \\
\text { ment of learn- } \\
\text { ing goals (i.e., } \\
\text { help cadets } \\
\text { learn, using an } \\
\text { appropriate } \\
\text { combination } \\
\text { and sequence } \\
\text { of learning } \\
\text { activities) } \\
10,6,20)\end{array}$ & $\begin{array}{l}\text { "Cover" course } \\
\text { content }\end{array}$ \\
\hline \multirow[t]{4}{*}{$\begin{array}{l}\text { Best practices } \\
\text { for creating deep } \\
\text { learning }\end{array}$} & $\begin{array}{l}\text { Cadets are } \\
\text { motivated to } \\
\text { learn (e.g., } \\
\text { because they } \\
\text { see the rel- } \\
\text { evance of the } \\
\text { topic) }(5,7,15 \text {, } \\
18,19)\end{array}$ & $\begin{array}{l}\text { Cadets are not } \\
\text { motivated to } \\
\text { learn (e.g., } \\
\text { because they } \\
\text { don't see the } \\
\text { relevance of } \\
\text { the topic) }\end{array}$ \\
\hline & $\begin{array}{l}\text { Cadets are } \\
\text { given good } \\
\text { sources of infor- } \\
\text { mation and } \\
\text { ideas }(9,10)\end{array}$ & $\begin{array}{l}\text { Cadets are not } \\
\text { given good } \\
\text { sources of } \\
\text { information } \\
\text { and ideas }\end{array}$ \\
\hline & $\begin{array}{l}\text { Cadets' learning } \\
\text { is within a con- } \\
\text { ceptual frame- } \\
\text { work }(12,15)\end{array}$ & $\begin{array}{l}\text { Cadets' } \\
\text { learning is } \\
\text { disorganized, } \\
\text { disjointed }\end{array}$ \\
\hline & $\begin{array}{l}\text { Cadets have } \\
\text { opportunities } \\
\text { to confront } \\
\text { their miscon- } \\
\text { ceptions }(5,15)\end{array}$ & $\begin{array}{l}\text { Cadets do not } \\
\text { have oppor- } \\
\text { tunities to } \\
\text { confront their } \\
\text { misconceptions }\end{array}$ \\
\hline
\end{tabular}

(Continued) 
Follow-on feedback areas: (Continued)

\begin{tabular}{|c|c|c|}
\hline Criterion & $\begin{array}{l}\text { Facilitates } \\
\text { Learning Best }\end{array}$ & $\begin{array}{l}\text { In Contrast } \\
\text { to . . }\end{array}$ \\
\hline & $\begin{array}{l}\text { Cadets' tasks } \\
\text { are challenging } \\
(5,15)\end{array}$ & $\begin{array}{l}\text { Cadets' tasks } \\
\text { are too easy / } \\
\text { hard }\end{array}$ \\
\hline & $\begin{array}{l}\text { Cadets spend } \\
\text { plentiful time } \\
\text { on task }(14,15)\end{array}$ & $\begin{array}{l}\text { Cadets spend } \\
\text { little time on } \\
\text { task }\end{array}$ \\
\hline & $\begin{array}{l}\text { Cadets interact } \\
\text { with instruc- } \\
\text { tor }(2,7,11,16)\end{array}$ & $\begin{array}{l}\text { Cadets do not } \\
\text { interact with } \\
\text { instructor }\end{array}$ \\
\hline & $\begin{array}{l}\text { Cadets inter- } \\
\text { act with each } \\
\text { other }(2,7,14,16 \text {, } \\
\text { 17) }\end{array}$ & $\begin{array}{l}\text { Cadets do not } \\
\text { interact with } \\
\text { each other }\end{array}$ \\
\hline & $\begin{array}{l}\text { Cadets have } \\
\text { opportunity } \\
\text { to reflect on } \\
\text { what and how } \\
\text { they are learn- } \\
\text { ing }(9.10,21)\end{array}$ & $\begin{array}{l}\text { Cadets do not } \\
\text { have opportu- } \\
\text { nity to reflect } \\
\text { on learning }\end{array}$ \\
\hline
\end{tabular}

\section{Assessment}

1. At some point during class, are cadets required to display what they have learned? $(5,11,21)$

YES NO

2. Was assessment well aligned with the learning $\operatorname{goal}(\mathrm{s})(4,7,10,19,21)$

YES NO

If "YES," how did cadets receive feedback? 
Follow-on feedback areas:

\begin{tabular}{|l|l|l|l|}
\hline Criterion & $\begin{array}{l}\text { Facilitates } \\
\text { Learning Best }\end{array}$ & $\begin{array}{l}\text { In Contrast } \\
\text { to . . }\end{array}$ \\
\hline $\begin{array}{l}\text { Inclusiveness } \\
\text { of Display }\end{array}$ & $\begin{array}{l}\text { All cadets dis- } \\
\text { play their learn- } \\
\text { ing (5, 11, 21) }\end{array}$ & $\begin{array}{l}\text { No cadets } \\
\text { display their } \\
\text { learning }\end{array}$ \\
\cline { 2 - 3 } Goal/Purpose & $\begin{array}{l}\text { Used to } \\
\text { facilitate cadet } \\
\text { learning (i.e., } \\
\text { educative) }(1,5, \\
\text { 10,20,21) }\end{array}$ & $\longrightarrow$ & $\begin{array}{l}\text { Used exclu- } \\
\text { sively to give } \\
\text { cadets a grade } \\
\text { (i.e., auditive) }\end{array}$ \\
\cline { 2 - 4 } & $\begin{array}{l}\text { Assessment } \\
\text { requires cadets } \\
\text { to use their } \\
\text { learning to } \\
\text { complete a real- } \\
\text { istic task (10,21) }\end{array}$ & $\longrightarrow$ & $\begin{array}{l}\text { Assessment } \\
\text { asks cadets to } \\
\text { simply recite } \\
\text { their knowl- } \\
\text { edge or follow } \\
\text { an established } \\
\text { procedure }\end{array}$ \\
\hline \multirow{5}{*}{$\begin{array}{l}\text { Criteria and } \\
\text { Standards }\end{array}$} & $\begin{array}{l}\text { Cadets are clear } \\
\text { on the criteria } \\
\text { and standards } \\
\text { used to evaluate } \\
\text { their work (10,21) }\end{array}$ & $\begin{array}{l}\text { Cadets are not } \\
\text { clear on the } \\
\text { criteria and } \\
\text { standards used } \\
\text { to evaluate } \\
\text { their work }\end{array}$ \\
\hline
\end{tabular}

\section{Feedback}

1. Do cadets receive feedback (from instructor or other cadets) about what they've learned? $(10,16,18,21)$

2. Does feedback provide information that will help cadets improve their learning? $(1,5,19,21)$ 


\section{Follow-on observation areas:}

\begin{tabular}{|l|l|l|l|}
\hline Criterion & $\begin{array}{l}\text { Facilitates } \\
\text { Learning Best }\end{array}$ & $\begin{array}{l}\text { In Contrast } \\
\text { to... }\end{array}$ \\
\hline $\begin{array}{l}\text { Inclusiveness } \\
\text { of feedback }\end{array}$ & $\begin{array}{l}\text { All cadets } \\
\text { receive feed- } \\
\text { back on their } \\
\text { learning (10, 16, } \\
18,21)\end{array}$ & $\begin{array}{l}\text { No cadets } \\
\text { receive } \\
\text { feedback on } \\
\text { their learning }\end{array}$ \\
\cline { 2 - 4 } $\begin{array}{l}\text { Promptness of } \\
\text { feedback }\end{array}$ & $\begin{array}{l}\text { Feedback } \\
\text { is provided } \\
\text { quickly, so that } \\
\text { it can be used } \\
\text { to improve (10, } \\
11,19)\end{array}$ & & $\begin{array}{l}\text { Feedback is } \\
\text { provided slowly, } \\
\text { making it dif- } \\
\text { ficult to use for } \\
\text { improvement }\end{array}$ \\
\cline { 2 - 4 } $\begin{array}{l}\text { Improvement/ } \\
\text { Use of Feedback }\end{array}$ & $\begin{array}{l}\text { Instructor and } \\
\text { cadets use feed- } \\
\text { back to improve } \\
\text { learning (1,5, } \\
10,21)\end{array}$ & $\longrightarrow \begin{array}{l}\text { Instructor and } \\
\text { cadets do not } \\
\text { use feedback } \\
\text { to improve } \\
\text { learning }\end{array}$ \\
\hline
\end{tabular}

\section{Sources Used in the Development of the Form}

1. Angelo, T. A., \& Cross, K. P. (1993). Classroom assessment techniques: A handbook for college teachers (2nd ed.). San Francisco: Jossey-Bass.

2. Astin, A. (1993). What matters in college? Four critical years revisited. San Francisco: Jossey-Bass.

3. Association of American Colleges and Universities. (2007). College learning for the new global century: A report from the National Leadership Council for Liberal Education EO America's Promise. Washington, DC: Author.

4. Association of American Colleges and Universities. (2002). Greater expectations: A new vision for learning as a nation goes to college. Washington, DC: Author.

5. Bain, K (2004). What the best college teachers do. Cambridge, MA: Harvard University Press.

6. Barr, R. B., \& Tagg, J. (1995). From teaching to learning: A new paradigm for undergraduate education. Change, 27(6), 13-25.

7. Biggs, J. (1999). What the student does: Teaching for enhanced learning. Higher Education Research and Development, 18(1), 57-75. 
8. Bok, D. (2006). Our underachieving colleges: A candid look at how much students learm and why they should be learming more. Princeton, NJ: Princeton University Press.

9. Bonwell, C. C., \&c Eison, J. A. (1991). Active learning: Creating excitement in the classroom. San Francisco: Jossey-Bass.

10. Fink, L. D. (2003). Creating significant learning experiences: An integrated approach to designing college courses. San Francisco: Jossey-Bass.

11. Gardiner, L. F. (1998, Spring). Why we must change: The research evidence. Thought $\mathcal{E}^{2}$ Action, 15, 71-87.

12. King, A. (1993). From sage on the stage to guide on the side. College Teaching, 41(1), 30-35.

13. Kuh, G. D., Kinzie, J., Schuh, J. H., \& Whitt, E. J. (2005). Student success in college: Creating conditions that matter. San Francisco: Jossey-Bass.

14. McKeachie, W. J., Pintrich, P. R., Lin, Y., \& Smith, D. A. F. (1986). Teaching and learning in the college classnom: A review of the research literature. Ann Arbor, MI: National Center for Research to Improve Postsecondary Teaching and Learning, University of Michigan.

15. National Research Council. (2000). How people learn: Brain, mind, experience, and school. Washington, DC: National Academy Press.

16. Pascarella, E. T., \& Terenzini, P. T. (1991). How college affects students. San Francisco: Jossey-Bass.

17. Prince, M. (2004). Does active learning work? A review of the research. Journal of Engineering Education, 93(3), 223-231.

18. Tagg, J. (2004, May-June). Alignment for learning: Reorganizing classrooms and campuses. About Campus, 8-18.

19. Walvoord, B. E., \& Anderson, V. J. (1998). Effective grading: A tool for learning and assessment. San Francisco: Jossey-Bass.

20. Weimer, M. (2002). Learner-centered teaching: Five key changes to practice. San Francisco: Jossey-Bass.

21. Wiggins, G. (1998). Educative assessment: Designing assessments to inform and improve student performance. San Francisco: Jossey-Bass.

\section{References}

Arons, A. B. (1979). Some thoughts on reasoning capacities implicitly expected of college students. In J. Lochhead \& J. Clement (Eds.), Cognitive process instruction: Research on teaching thinking skills (pp. 209-216). Philadelphia: The Franklin Institute Press.

Arons, A. B. (1997). Teaching introductory physics. New York: Wiley.

Association of American Colleges and Universities. (2007). College learning for the new global century: A report from the National Leadership Council for Liberal Education and America's Promise. Washington, DC: Author. 
Barr, R., \& Tagg, J. (1995, November/December). From teaching to learning-A new paradigm for undergraduate education. Change, $27(6), 12-25$.

Biggs, J. B. (1999). What the student does: Teaching for enhanced learning. Higher Education Research and Development, 18(1), 57-75.

Bok, D. (2006). Our underachieving colleges: A candid look at how much students learn and why they should be learning more. Princeton, NJ: Princeton University Press.

Campbell, W. E., \& Smith, K. A. (Eds.). (1997). New paradigms for college teaching. Edina, MN: Interaction Book Company.

Donald, J. G. (2002). Leaming to think: Disciplinary perspectives. San Francisco: Jossey-Bass.

Durisen, R., \& Pilachowski, C. (2004). Decoding astronomical concepts. In D. Pace \& J. Middendorf (Eds.), New directions for teaching and learming: No. 98. Decoding the disciplines: Helping students learn disciplinary ways of thinking (pp. 33-43). San Francisco: Jossey-Bass.

Fink, L. D. (2003). Creating significant learning experiences: An integrated approach to designing college courses. San Francisco: Jossey-Bass.

Hake, R. R. (1998). Interactive-engagement vs. traditional methods: A six-thousand student survey of mechanics test data for introductory physics courses. American Journal of Physics, 66(1), 64-74.

Hersh, R. H., \& Merrow, J. (Eds.). (2005). Declining by degrees: Higher education at risk. New York: Palgrave Macmillan.

Higher Learning Commission. (2007). Institutional accreditation: An overview. Retrieved March 7, 2008, from http://hlcommission.org/ download/Overview07.pdf

Huba, M. E., \& Freed, J. E. (2000). Learner-centered assessment on college campuses: Shifting the focus from teaching to learning. Boston: Allyn \& Bacon.

King, A. (1993). From sage on the stage to guide on the side. College Teaching, 41(1), 30-35.

National Research Council. (2000). How people learn: Brain, mind, experience, and school. Washington, DC: National Academy Press.

National Survey of Student Engagement. (2005). Exploring different dimensions of student engagement. Retrieved November 17, 2005, from http://nsse.iub.edu/pdf/NSSE2005_annual_report.pdf

Tagg, J. (2003). The learning paradigm college. Bolton, MA: Anker.

U.S. Department of Education. (2006). A test of leadership: Charting the future of U.S. higher education. Washington, DC: Author.

Wiggins, G. (1998). Educative assessment: Designing assessments to inform and improve student performance. San Francisco: Jossey-Bass. 